\title{
Basic factors predicting prostate cancer in Prostate Imaging Reporting and Data System-3 lesions
}

\author{
Prostat Görüntüleme Raporlama ve Veri Sistemi-3 lezyonlarında prostat kanserini öngören \\ temel faktörler
}

\author{
Sercan Yılmaz', Mehmet Yılmaz², Serdar Yalcın', Engin Kaya', Eymen Gazel ${ }^{3}$, Halil Cagrı Aybal ${ }^{4}$, Hakan Özdemir ${ }^{5}$, \\ Mehmet Yorubulut ${ }^{6}$, Ali Yusuf Oner ${ }^{7}$, Lutfi Tunc ${ }^{8}$ \\ 1 Health Sciences University, Gulhane Training and Research Hospital, Department of Urology, Ankara, Turkey \\ 2 Zile State Hospital, Department of Urology, Tokat, Turkey \\ 3 Acıbadem University Ankara Hospital, Department of Urology, Ankara, Turkey \\ 4 Kahramankazan Hamdi Eris State Hospital, Department of Urology, Ankara, Turkey \\ 5 Diason Ultrasonography Center, Ankara, Turkey \\ 6 Acibadem University, Ankara Hospital, Department of Radiology, Ankara, Turkey \\ 7 Gazi University School of Medicine, Department of Radiology, Ankara, Turkey \\ 8 Gazi University School of Medicine, Department of Urology, Ankara, Turkey
}
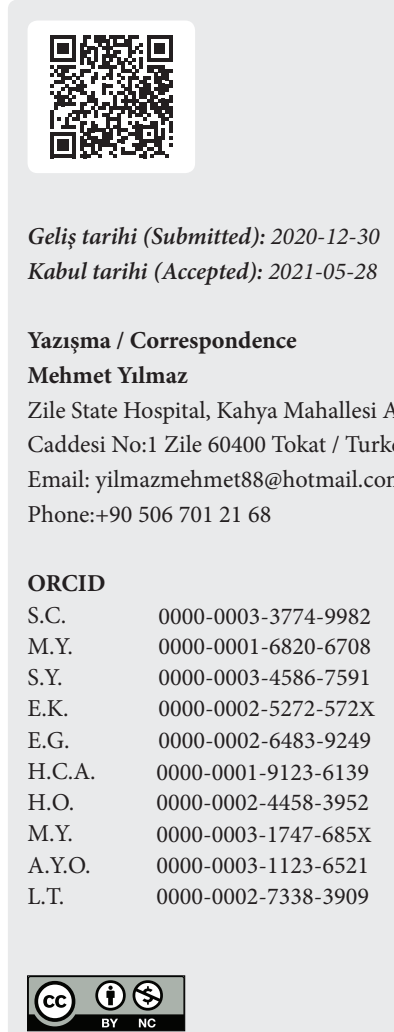

This work is licensed under a Creative Commons Attribution-NonCommercial 4.0 International License.
Özet

Amaç: Bu çalışmada Prostat Görüntüleme ve Veri Raporlama Sistemi (PI-RADS) 3 lezyonlarında prostat kanserini öngörmede dijital rektal muayene ile PSA dansitesi, lezyonun bölgesel konumu ve prostat boyutunun rolünü araştırmak istedik.

Gereç ve Yöntemler: PSA düzeyi yükselmiş ve / veya dijital rektal muayenesi şüpheli olması nedeniyle multiparametrik MR çekilmiş ve biyopsi sonucu PI-RADS 3 olarak raporlanmış toplam 236 hastanın verileri retrospektif olarak incelendi. Prostat kanseri tespit oranı, dijital rektal muayene bulguları, lezyonların yeri, PSA dansite sonuçları, prostat hacmi sonuçları ve alt grup analizleri ile risk sınıflandırılması yapıldı.

Bulgular: PI-RADS Skoru 3 olan 137 hasta çalışmaya dahil edildi. Genel prostat kanseri tespit oranı \% 26,2 ve klinik önemli prostat kanseri tespit oranı \% 4,3'tü. Dijital rektal muayene bulguları ( $\mathrm{p}=0,001)$ ve lezyonun periferik zon yerleșimi $(\mathrm{p}=0,005)$ ile prostat kanseri olmayan gruplar arasında anlamlı farklılık bulundu. Dijital rektal muayene ( $\mathrm{p}=0.001)$, çok değişkenli lojistik regresyon analizinde PIRADS-3 lezyonlu hastalarda prostat kanserinin bağımsız prediktörü olarak tespit edildi.

Sonuç: Dijital rektal muayene, PI-RADS 3 lezyonu olan hastalarda prostat kanseri şüphesini ortaya koymak açısından pratik ve önemli bir parametredir.
Abstract

Objective: We aimed to investigate the role of the digital rectal examination, PSA density, regional location of the lesion and prostate size in predicting prostate cancer in Prostate Imaging and Data Reporting System (PI-RADS)-3 lesions.

Material and Methods: A total of 236 patients with multiparametric MRI performed for clinical suspicion of prostate cancer and reported PIRADS-3 enrolled between January 2016 and July 2019 in this retrospective study. The datas were extracted from the hospital's electronic records, patient files and outpatient clinic records. Multiparametric MRI was performed patients to whom have elevated PSA level and/or suspicious digital rectal examination. Patients diagnosed with and without prostate cancer were compared in terms of age, PSA, PSA density, prostate size, pathological results, lesion localization and DRE findings.

Results: One hundred thirty- independent predictor seven patients with an initial score of PIRADS-3 were subjected to further analysis. Prostat cancer detection rate in overall and clinically significant prostate cancer detection rate was $26.2 \%$ and $4.3 \%$, respectively. There was a significant difference regarding DRE findings $(\mathrm{p}=0.001)$ and $\mathrm{PZ}$ location of the lesion $(\mathrm{p}=0.005)$ between $\mathrm{PCa}$ and no PCa groups. Digital rectal examination $(p=0.001)$ was an independent predictor of prostate cancer in multivariate logistic regression analysis.

The study was approved by the Assessment and Evulation Ethichal Sub-committee of Gazi University (Approval Number: 2019-289. 26 July, 2019). All research was performed in accordance with relevant guidelines/regulations, and informed consent was obtained from all participants. 
Anahtar Kelimeler: prostat kanseri, dijital rektal muayene, magnetik rezonans görüntüleme
Conclusion: Digital rectal examination is a practical and important parameter in clarifying the suspicion of prostate cancer in PI-RADS-3 lesions.

Keywords: prostatic neoplasms, digital rectal examination, multiparametric magnetic resonance imaging, image guided biopsy

\section{INTRODUCTION}

Prostate cancer $(\mathrm{PCa})$ is the most common cancer among men and it is mainly suspected in prostate-specific antigen (PSA) test and/or digital rectal examination (DRE)(1). The identification of this suspicion is classically solved by transrectal ultrasound-guided prostate biopsy (TRUS-Bx). The prostate cancer detection rate of TRUS-Bx is $20-40 \%$ (2). The risks after the procedure such as sepsis and hemorrhage and invasiveness of the procedure required new approaches(3). With the use of prostate multiparametric magnetic resonance imaging (mpMRI) in evaluation of the PCa, MRI-guided fusion prostate biopsy (MRI-FPBx) has become a rising star technique(4).

Prostate Imaging Reporting and Data System (PIRADS) was defined considering malignancy characteristics of the lesions detected in prostate $\operatorname{MRI}(5,6)$. In the grading system, PI-RADS- 1 and 2 scores are considered insignificant in terms of malignancy potential, while PI-RADS- 4 and 5 are determined to have high malignancy potential. However, PI-RADS 3 lesions mostly termed as "equivocal" in terms of malignancy potential.

Many biochemical (PSA, PSA density, etc.) or radiological parameters (prostate size, zonal location of the lesion) are used to determine the risk of Prostate Cancer. Especially in PI-RADS-3 lesions, when these parameters are combined with MRI findings, the prediction of prostate cancer may increase. It is known that the role of DRE is important in supporting a suspicion of prostate cancer in a patient with elevated PSA(7). However, there is no study on the predictivity of DRE in determining prostate cancer in patients with PI-RADS-3 lesions.

We aimed to investigate the role of the digital rectal examination, PSA density (PSAD), regional location of the lesion and prostate size in predicting prostate cancer in PI-RADS-3 lesions.

\section{MATERIAL AND METHODS}

Institutional review board approval was obtained (ID: 2019-289). Informed consent was obtained by all subjects when they were enrolled. This study was conducted in accordance with the Declaration of Helsinki.

\section{Patient selection}

A total of 236 patients who underwent biopsy for PI-RADS-3 lesions between January 2016 and July 2019 were included in the study. The data were extracted from the hospital's electronic records, patient files and outpatient clinic records. Patients who were unwilling for DRE $(n=16)$ or absence the data of DRE $(n=18)$, patients who do not want their data to be used in the study $(\mathrm{n}=18)$ and patients with incomplete data ( $n=47)$ were excluded from the study, and 137 patients with an initial score of PI-RADS 3 were subjected to further analysis and divided into two groups as $\mathrm{PCa}$ and 'no PCa'. PCa and 'no PCa' groups were compared in terms of age, PSA, PSA density, prostate size, pathological results, lesion localization and DRE findings.

Prostate Cancer was not diagnosed in any patient prior to mpMRI procedure. Multiparametric MRI was performed for elevated PSA level (Normal range: 0-4 $\mathrm{ng} / \mathrm{dL}$ ) and/or suspicious DRE. All DREs were performed in the left lateral decubitus position and were considered suspicious in the presence of nodularity, induration, significant asymmetry or loss of anatomical landmarks. The end points were determined as follows; 1) PCa detection rate, 2) DRE findings 3) location of lesions, 4) PSAD (Normal range: $\leq 0.15 \mathrm{ng} / \mathrm{mL} / \mathrm{mL}$ ) results, 5) prostate volume results and 6) risk stratification by subgroup analyses.

\section{Multiparametric MRI}

All mpMRIs were applied using 1.5 or 3 Tesla magnetic field strength and a pelvic phased-array coil in accordance with the recommendations of a European consensus meeting(8). As MRI sequences, T1-weight- 
ed, T2-weighted and diffusion-weighted and dynamic gadolinium-contrast images were evaluated(8). Regardless of the previous report each mpMRI scan was again interpreted by two radiologists experienced in prostate MRI according to PI-RADS v2 and who were blinded to the clinical context (MY\&AYO). All prostate volumes were calculated on axial and sagittal T2-weighted images (height $\mathrm{X}$ width $\mathrm{X}$ depth/2).

\section{The Procedure of MRI-US FPBx}

All procedures were performed by single uro-radiologist (HO) experienced in prostate biopsy at least 20-years with LOGIQ E9॰ (General Electric, MA, USA) ultrasonography device combined rigid fusion software. Before the procedures, mpMRI images of the patients were uploaded to the US software system and initially the lesions were marked on T2-weighted axial images. Three-core fusion biopsy was obtained from each marked lesion. Initially, targeted biopsy was performed and subsequently systematic 12-core TRUS-Bx was obtained from the peripheral zone of the prostate as known classically.

\section{Pathological Evaluation}

A single pathologist who has more than 20 years of experience in uropathology evaluated all pathologic specimens. All pathological examinations were performed according to 2014 International Society of Urological Pathology (ISUP) grading system(9). Gleason score (GS) $3+4$ or greater (ISUP $\geq 2$ ) was defined as clinically significant PCa.

\section{Data Analysis}

Demographic data, the data of serum PSA level, prostate volume, PSAD and DRE findings, mpMRI and MRI-FPBx were collected retrospectively and evaluated according to Standards of Reporting for MRI-targeted Biopsy Studies recommendations(10). PSAD was calculated by dividing PSA level by prostate volume assessed with MRI.

\section{Statistical Analysis}

The Statistical Package for Social Sciences 23.0 software (SPSS 20.0, Chicago, IL, USA) was utilized. Conformity to the normality of the data was assessed by the Kolmogorov-Smirnov, Kurtosis, and Skewness Tests. Descriptive statistics of scale samples were expressed as mean \pm standard deviation or median \pm inter-quartile range (IQR). If the defined group had normal distribution, it was expressed as mean \pm standard deviation; otherwise expressed as median \pm inter-quartile range. Mann Whitney $U$ or Student t-test for continuous variables were used for comparing the clinical characteristics of the two groups. Pearson Chi-Square test or Fisher's Exact test were used to assess categorical variables. Univariate and multivariate analysis using logistic regression identified significant predictors of $\mathrm{PCa}$. 95\% confidence intervals (CIs) were determined. All statistical tests were two-sided, with $\mathrm{p}<0.05$ considered as statistically significant.

\section{RESULTS}

Of 137 patients, 101 were reported benign and 36 were malign. There were no significant differences in terms of age, PSA, PSAD and prostate size between groups. The detailed characteristics of the groups are given in Table 1.

Prostat cancer detection rate in overall and clinically significant prostate cancer detection rate was $26.2 \%$ and $4.3 \%$, respectively. Five patients with clinically significant PCa diagnosed as GS $3+4$ and 1 was as GS $4+3$, the remainings diagnosed as GS $3+3$. The pathological results of eleven samples in benign group were reported as atypical small acinar proliferation (ASAP).

Twenty-nine (80.5\%) patients of malign group and $41(40.6 \%)$ of benign group patients, DRE findings were positive while 7 (19.5\%) and 60 (59.4\%) of those had negative DRE findings, respectively. A total of 165 lesions were biopsied. One hundred eighteen of 165 lesions were localized in the peripheral zone (PZ) and 47 lesions were in the transitional zone (TZ). There was a significant difference regarding DRE findings $(\mathrm{p}=0.001)$ and PZ location of the lesion $(\mathrm{p}=0.005)$ between PCa and no PCa groups (Table 2).

Table 3 shows univariate and multivariate logistic regression analyses to detect prostate cancer predictors. Univariate logistic regression analysis showed that DRE ( $\mathrm{p}=0.001)$ was a significant predictor of PCa while PZ location $(\mathrm{p}=0.99)$ was insignificant. Age, PSA, PSAD and prostate volume data were excluded from multivariate analysis to avoid confounding. Digital rectal examination was found as an independent predictor of $\mathrm{PCa}$ in multivariate logistic regression analysis $(\mathrm{p}=0.001)$. 
Table 1. Patient characteristics of groups and prostate cancer detection

\begin{tabular}{|c|c|c|c|}
\hline & $\operatorname{PCa}(n=36)$ & No PCa $(n=101)$ & $\mathbf{P}$ \\
\hline Age , years, mean ${ }^{*}$ & $63.4 \pm 8.6$ & $61.2 \pm 7.6$ & 0.15 \\
\hline PSA, ng/mL, median & $5.82 \pm 3.5 \mathrm{IQR}$ & $6.51 \pm 4.29 \mathrm{IQR}$ & 0.12 \\
\hline PSAD, ng $/ \mathrm{mL}^{2}$, median & $0.08 \pm 0.09 \mathrm{IQR}$ & $0.09 \pm 0.08 \mathrm{IQR}$ & 0.61 \\
\hline Prostate size, cc, mean & $49 \pm 50$ & $62 \pm 25.5$ & 0.06 \\
\hline \multicolumn{4}{|l|}{ Pathologic result, $\mathrm{No}(\%)$} \\
\hline$A S A P$ & & $11(10.8)$ & \\
\hline GS $3+3$ & $30(83.3)$ & & \\
\hline GS $3+4$ & $5(13.8)$ & & \\
\hline GS $4+3$ & $1(2.7)$ & & \\
\hline
\end{tabular}

IQR: Inter-quartile range, PCa: Prostate cancer, PSA: prostate specific antigen, PSAD: prostate specific antigen density ASAP: Atypical small acinar proliferation, GS: Gleason score ${ }^{\star}$ Analyzed with Student $t$-test; others analyzed with Mann Whitney U test

Table 2. Subgroup analysis of the parameters

\begin{tabular}{lccc}
\hline & PCa $(\mathbf{n}=\mathbf{3 6})$ & No PCa $(\mathbf{n}=\mathbf{1 0 1})$ & P \\
\hline DRE (+) patient No. & 29 & 41 & 0.001 \\
DRE (-) patient No. & 7 & 60 & 0.001 \\
PZ Lesion, No. & 36 & 82 & 0.005 \\
TZ Lesion, No. & 10 & 37 & 0.41 \\
\hline
\end{tabular}

DRE: Digital rectal examination, PZ: Peripheral zone, TZ: Transitional zone, PCa: Prostate cancer

${ }^{*}$ Analyzed with Fisher's Exact test; others analyzed with Pearson Chi-Square test

Table 3. Univariate and multivariate logistic regression analyzes to detect prostate cancer predictors

\begin{tabular}{|c|c|c|c|c|c|c|c|c|}
\hline & \multicolumn{4}{|c|}{ Univariate Analysis } & \multicolumn{4}{|c|}{ Multivariate Analysis } \\
\hline & \multirow{2}{*}{ OR } & \multicolumn{2}{|c|}{$95 \%$ CI } & \multirow{2}{*}{$P$} & \multirow{2}{*}{ OR } & \multicolumn{2}{|c|}{$95 \%$ CI } & \multirow{2}{*}{$P$} \\
\hline & & Min & Max & & & Min & $\operatorname{Max}$ & \\
\hline DRE & 6,06 & 2,42 & 15,15 & 0.001 & 0.165 & 0.066 & 0.412 & 0.001 \\
\hline PZ Lesion & 0 & 0 & 1 & 0,99 & 0 & 0 & 1 & 0.99 \\
\hline
\end{tabular}

OR: Odds ratio, CI: Confidence intervals, DRE: Digital rectal examination, PZ: Peripheral zone,

Analyzed with Logistic Binary Regression test

\section{DISCUSSION}

PI-RADS-3 lesions are mostly one-third of all mpMRI lesions and are considered to be "equivocal" in terms of malignancy features. Although various parameters such as PSA, PSAD, zonal location of the lesion and prostate volume were evaluated in order to increase the malignancy predictions of these lesions, their contribution in clinical practice is limited. In the present study, we evaluated the potential of DRE, PSAD, zonal location of lesion and prostate size in predicting prostate cancer in PI-RADS 3 lesions. We found that DRE was an independent predictor of $\mathrm{PCa}$ in PI-RADS-3 lesions.

The role of PSAD in determining malignancy predictivity in patients with suspected PCa has been reported in several studies(11-13). The role of PSAD in patients with PI-RADS-3 lesions was also evaluated(12, 14-17). Washino et al. noted that PSAD is an independent predictor of PCa. The authors suggested if PSAD score was detected as $0.15 \mathrm{ng} / \mathrm{mL} 2$ as a cut-off in patients with PI-RADS $\leq 3$, biopsy could be waived(12). In a study by Kim et al. including 138 pa- 
tients with PI-RADS 3 lesions, PSAD was found as an effective parameter in detecting $\mathrm{PCa}(14)$. Görtz et al. found that PSAD was a significant predictor of clinically significant PCa in patients with PI-RADS-3 lesions $(\mathrm{p}=0.005)(18)$. The authors stated that the inclusion of PSAD $<0.1 \mathrm{ng} / \mathrm{ml} / \mathrm{ml}$ in the biopsy strategy for patients with no biopsy history and with suspicious mpMRI findings would result in a $43 \%$ reduction in prostate biopsies. In another study, Ryoo et al. emphasized that prostate biopsy can be avoided in case of patients with PI-RADS-3 lesion, PSAD $<0.15 \mathrm{ng} / \mathrm{mL} / \mathrm{mL}$ and with no biopsy history(19). In our study, we did not find any statistically significant finding that PSAD increased PCa predictivity alone or in combination with other parameters in patients with PI-RADS-3 lesions.

Prostate size can have a role for the predictivity of prostate size in patients with clinical suspicion of PCa. Hermie et al. found that lower prostate volume can predict clinically significant prostate cancer in PI-RADS 3 lesions $(\mathrm{p}=0.015)(20)$. Similarly, Trapani et al. found a significant association between smaller prostate volume and prostate cancer in patients with PI-RADS-3 lesions(21). In the present study, patients in PCa group had lower prostate volume than no PCa group. However, there was no statistically significant difference between groups ( $49 \pm 50$ vs. $62 \pm 25.5 ; \mathrm{p}=0.06$ ).

The role of the zonal location in the prediction of malignancy of PI-RADS-3 lesions has been evaluated. Ullrich et al. found that malignancy rates of lesions located in the peripheral zone were higher in patients with PI-RADS 3 lesions(16). Similarly, in another study, it was found that clinically significant prostate cancer rate was higher in the peripheral zone than the transitional zone (13.7\% vs. $6.2 \%$ ), in patients with PIRADS-3 lesions(14). In addition, the peripheral zone location was found as one of the independent pedictors of total PCa and clinically significant PCa in PIRADS-3 lesions(14). In the present study, PCa was common in the peripheral zone than the transitional zone $(\mathrm{p}=0.005)$. However, it was not found as a predictor of PCa.

Digital rectal examination still remains important in the diagnosis of prostate cancer. Omri et al. demonstrated that patients who underwent targeted biopsy had a higher rate of significant cancer per core in the presence of positive DRE findings(22). Hermie et al. stated that a suspicious digital rectal examination impacts clinicians to perform prostate biopsy in patients with PI-RADS-3 lesions(20). However, it is debatable why DRE is not taken into account, although it is a basic physical examination procedure. From the perspective of the clinician, there may be two reasons: First, it is clear that since prostate mpMRI came on the agenda, teamwork among radiologists and urologists has emerged. However, if there is a lack of coordination between the two teams, it is obvious that some parts of the evaluation will be missing. Frankly, DRE is mostly performed by urologists. We believe that DRE findings should be documented and shared with radiologists who perform and interpret mpMRI. Second, it was clear that DRE might be a cause of embarrassment and discomfort for patients. Nevertheless, the importance of DRE should be adequately explained to the patient by the clinician and then the patient should be asked to make the final decision.

There are certain limitations of this study. First, our study was designed retrospectively; therefore, selection bias may be a risk factor. Second, our study included small sample size that led to the underestimation of the predictive value. Third, there is the lack of comparison with prostatectomy data as reference standard. Therefore, we could not completely find out the real significance of a negative biopsy. Last but not least, lesion sizes and the other PSA derives could not be evaluated due to the lack of data on lesion sizes.

\section{CONCLUSION}

Digital rectal examination is a practical and important parameter in clarifying the suspicion of prostate cancer in PI-RADS-3 lesions.

\section{Conflict of Interest}

The authors have no conflicts of interest to declare.

\section{Financial Disclosure}

The authors declared that this study has received no financial support.

\section{Ethical Approval}

This study was approved by the Assessment and Evulation Ethichal Sub-committee of Gazi University (Approval Number: 2019-289. 26 July, 2019), and written informed consent was obtained from the patients. 


\section{REFERENCES}

1. Center MM, Jemal A, Lortet-Tieulent J, Ward E, Ferlay $\mathrm{J}$, Brawley $\mathrm{O}$, et al. International variation in prostate cancer incidence and mortality rates. European urology. 2012;61:1079-92.

2. Trabulsi EJ HE, Gomella LG. Ultrasonography and biopsy of the prostate. 10 ed. Philadelphia: Saunders; 20112011. 2735-47 p.

3. Pinkhasov GI, Lin YK, Palmerola R, Smith P, Mahon F, Kaag MG, et al. Complications following prostate needle biopsy requiring hospital admission or emergency department visits - experience from 1000 consecutive cases. BJU international 2012;110:369-74

4. Scheenen TW, Rosenkrantz AB, Haider MA, Futterer JJ. Multiparametric Magnetic Resonance Imaging in Prostate Cancer Management: Current Status and Future Perspectives. Investigative radiology 2015;50:594-600

5. Barentsz JO, Richenberg J, Clements R, Choyke P, Verma S, Villeirs G, et al. ESUR prostate MR guidelines 2012. European radiology 2012;22:746-57.

6. Weinreb JC, Barentsz JO, Choyke PL, Cornud F, Haider MA, Macura KJ, et al. PI-RADS Prostate Imaging - Reporting and Data System: 2015, Version 2. European urology. 2016;69:16-40.

7. Carroll PR, Parsons JK, Andriole G, Bahnson RR, Castle EP, Catalona WJ, et al. NCCN Guidelines Insights: Prostate Cancer Early Detection, Version 2.2016. Journal of the National Comprehensive Cancer Network : JNCCN 2016;14:509-19.

8. Dickinson L, Ahmed HU, Allen C, Barentsz JO, Carey B, Futterer JJ, et al. Magnetic resonance imaging for the detection, localisation, and characterisation of prostate cancer: recommendations from a European consensus meeting. European urology 2011;59:477-94.

9. Epstein JI, Egevad L, Amin MB, Delahunt B, Srigley JR, Humphrey PA. The 2014 International Society of Urological Pathology (ISUP) Consensus Conference on Gleason Grading of Prostatic Carcinoma: Definition of Grading Patterns and Proposal for a New Grading System. The American journal of surgical pathology 2016;40:244-52.

10. Moore CM, Kasivisvanathan V, Eggener S, Emberton M, Futterer JJ, Gill IS, et al. Standards of reporting for MRI-targeted biopsy studies (START) of the prostate: recommendations from an International Working Group. European urology 2013;64:544-52.

11. Bul M, Zhu X, Valdagni R, Pickles T, Kakehi Y, Rannikko A, et al. Active surveillance for low-risk prostate cancer worldwide: the PRIAS study. European urology 2013;63:597-603.

12. Washino S, Okochi T, Saito K, Konishi T, Hirai M, Kobayashi $\mathrm{Y}$, et al. Combination of prostate imaging reporting and data system (PI-RADS) score and prostate-specific antigen (PSA) density predicts biopsy outcome in prostate biopsy naive patients. BJU international. 2017;119:225-33.

13. Hansen NL, Kesch C, Barrett T, Koo B, Radtke JP, Boneka$\mathrm{mp} \mathrm{D}$, et al. Multicentre evaluation of targeted and systematic biopsies using magnetic resonance and ultrasound image-fusion guided transperineal prostate biopsy in patients with a previous negative biopsy. BJU international 2017;120:631-8.

14. Kim TJ, Lee MS, Hwang SI, Lee HJ, Hong SK. Outcomes of magnetic resonance imaging fusion-targeted biopsy of prostate imaging reporting and data system 3 lesions. World journal of urology 2019;37:1581-6.

15. Cuocolo R, Stanzione A, Rusconi G, Petretta M, Ponsiglione A, Fusco F, et al. PSA-density does not improve bi-parametric prostate MR detection of prostate cancer in a biopsy naive patient population. European journal of radiology 2018;104:64-70.

16. Ullrich T, Quentin M, Arsov C, Schmaltz AK, Tschischka A, Laqua N, et al. Risk Stratification of Equivocal Lesions on Multiparametric Magnetic Resonance Imaging of the Prostate. The Journal of urology 2018;199:691-8.

17. Brizmohun Appayya M, Sidhu HS, Dikaios N, Johnston EW, Simmons LA, Freeman A, et al. Characterizing indeterminate (Likert-score 3/5) peripheral zone prostate lesions with PSA density, PI-RADS scoring and qualitative descriptors on multiparametric MRI. The British journal of radiology 2018;91:20170645.

18. Gortz M, Radtke JP, Hatiboglu G, Schutz V, Tosev G, Guttlein M, et al. The Value of Prostate-specific Antigen Density for Prostate Imaging-Reporting and Data System 3 Lesions on Multiparametric Magnetic Resonance Imaging: A Strategy to Avoid Unnecessary Prostate Biopsies. Eur Urol Focus 2021;7:325-31.

19. Ryoo H, Kang MY, Sung HH, Chang Jeong B, Seo SI, Jeon SS, et al. Detection of prostate cancer using prostate imaging reporting and data system score and prostate-specific antigen density in biopsy-naive and prior biopsy-negative patients. Prostate Int. 2020;8:125-9.

20. Hermie I, Van Besien J, De Visschere P, Lumen N, Decaestecker K. Which clinical and radiological characteristics can predict clinically significant prostate cancer in PI-RADS 3 lesions? A retrospective study in a high-volume academic center. European journal of radiology 2019;114:92-8.

21. Di Trapani E, Musi G, Ferro M, Cordima G, Mistretta FA, Luzzago S, et al. Clinical evaluation and disease management of PI-RADS 3 lesions. Analysis from a single tertiary high-volume center. Scand J Urol 2020:1-5.

22. Omri N, Alex S, Jacob B, Ofer N. The additive value of $\mathrm{mp}$ MRI on prostate cancer detection: Comparison between patients with and without a suspicious digital rectal examination (DRE). Urologic oncology 2021. 